\title{
Various textured soil as nitrous oxide emitter and consumer
}

\author{
T. Włodarczyk ${ }^{1}$, W. Stepniewski ${ }^{2}$, M, Brzezińska ${ }^{1}$, and U. Majewska ${ }^{1}$ \\ ${ }^{1}$ Institute of Agrophysics, Polish Academy of Sciences, Doświadczalna 4, 20-290 Lublin, Poland \\ ${ }^{2}$ University of Technology, Nadbystrzycka 40b, 20-618 Lublin, Poland
}

Received November 22, 2010; accepted April 2, 2011

\begin{abstract}
A b s tra ct. Changes of $\mathrm{NO}_{3}$, and $\mathrm{N}_{2} \mathrm{O}$ concentrations during 34 days hypoxic incubation of eleven nitrate amended samples of the Eutric Cambisols developed from sand, silt and loam were studied. It was found that initial generation of nitrous oxide was followed, after a maximum by its subsequent absorption. The absorption rate was correlated with the efflux. Both were negatively correlated with sand content and positively with silt, clay and $\mathrm{C}_{\text {org }}$. The percentage of nitrate reduced equals 35,97 , and $100 \%$ for Eutric Cambisols developed from sand, loam and silt, respectively. The highest $\mathrm{N}_{2} \mathrm{O}$ efflux was observed from silty soils, the lowest one from sandy soils. Total $\mathrm{N}_{2} \mathrm{O}$ consumption ranged between 3.3 and $66.5 \mathrm{mg} \mathrm{N} \mathrm{kg}^{-1}$, and consisted 32.9, 99.2, and $100 \%$ of the produced $\mathrm{N}_{2} \mathrm{O}$ for the sandy, loamy and silty soil samples, respectively. The tested soils were characterized by various ratio of the $\mathrm{N}_{2} \mathrm{O}$ emitted to the consumed. Most of sandy samples are characterized by a weak capacity to $\mathrm{N}_{2} \mathrm{O}$ production and consumption, while loamy and silty soils are characterized by a good or very good capacity to $\mathrm{N}_{2} \mathrm{O}$ production and consumption.

$\mathrm{K}$ e y w o r d s: soil, nitrous oxide, emission, consumption, nitrate reducing
\end{abstract}

\section{INTRODUCTION}

Greenhouse gas emissions to the atmosphere and their contribution to climate change have attracted world-wide attention. Concentrations of atmospheric greenhouse gases (GHGs), such as carbon dioxide $\left(\mathrm{CO}_{2}\right)$, methane $\left(\mathrm{CH}_{4}\right)$, and nitrous oxide $\left(\mathrm{N}_{2} \mathrm{O}\right)$, which can alter the Earth climate, have risen dramatically during the past century. This has resulted in an urgent need for process-based understanding of the main factors influencing the exchange of these gases between the land and atmosphere at a range of scales, as a route to developing effective mitigation technologies. Accordingly, the measurement and reduction of these gaseous emissions

\footnotetext{
*Corresponding author's e-mail: teresa@ipan.lublin.pl
}

have become a global imperative, attracting the interest of researchers and policy makers alike (Kutilek and Nielsen, 2010; Saggar, 2010). Aside from carbon dioxide, the most significant are methane, and nitrous oxide that have a potential for global warming because of increasing man-made emission (Khalil, 2000). The global warming potential of nitrous oxide is about 320 times higher than that of $\mathrm{CO}_{2}$. Current atmospheric abundance is alarmingly increasing in various sectors (Verma et al., 2006). The residence time of $\mathrm{N}_{2} \mathrm{O}$ in the atmosphere is estimated to be about 150 years (Khalil and Rasmussen, 1992). This indicates that there are neither reactions with other chemicals present in the atmosphere nor removal with precipitation water (Verma et al., 2006).

Denitrification, or dissimilative nitrate reduction, is an anaerobic process used by some bacteria for energy generation. This process is important in many aspects, but its environmental implications have been given particular relevance. Nitrate accumulation and release of nitrous oxide in the atmosphere due to excess use of fertilizers in agriculture are examples of two environmental problems where denitrification plays a main role (Tavares et al., 2006).

Under certain aeration conditions in soil, nitrous oxide is formed (Huang et al., 2007; Li et al., 2006). It can be generated or absorbed in soil depending on the redox potential (Gliński and Stępniewski, 1985). Nitrous oxide can be produced at a certain soil layer and absorbed in the deeper, more reduced horizons or oxidized during its migration to the atmosphere. Closer to the surface it can be produced again due to nitrification. Thus the net emission or absorption of nitrous oxide at the soil surface will depend on soil aeration status (Seo and DeLaune, 2010; Stępniewski and Stępniewska, 2009). 
Despite the importance of nitrous oxide as a greenhouse gas and its role in destroying stratospheric ozone, its global budget remains poorly understood (Khalil, 2000). Two aspects of $\mathrm{N}_{2} \mathrm{O}$ research in agricultural ecosystems that limit our understanding of and the ability to accurately predict and manage $\mathrm{N}_{2} \mathrm{O}$ are:

- the information on $\mathrm{N}_{2} \mathrm{O}$ emission from plants and,

- atmospheric $\mathrm{N}_{2} \mathrm{O}$ consumption by soils.

The aim of the present paper was: to characterize:

- the nitrate reduction to $\mathrm{N}_{2} \mathrm{O}$ in Ap horizon samples from the Eutric Cambisols under limited oxygen availability, - subsequent their $\mathrm{N}_{2} \mathrm{O}$ consumption in the headspace.

\section{MATERIALS AND METHODS}

Soil samples were taken from 11 Ap horizons $(0-30 \mathrm{~cm})$ and used in the study after drying pretreatment. The Eutric Cambisols were developed from different parent materials: sands (Nos 1-4), silts (Nos 5-7) and loams (Nos 8-11). The soil texture was determined by standard sedimentation method. The Eutric Cambisols showed a large variation of the soil texture, $\mathrm{C}_{\text {org. }}$, endogenous $\mathrm{NO}_{3}{ }^{-}$content and $\mathrm{pH}$ (Table 1).

The $5 \mathrm{~g}$ portions of air-dried sieved ( $1 \mathrm{~mm}$ sieve) the Eutric Cambisols were placed in $38 \mathrm{~cm}^{3}$ glass vessels and enriched with $\mathrm{KNO}_{3}$ at the rate of $100 \mathrm{mg} \mathrm{NO}_{3}{ }^{-}-\mathrm{N} \mathrm{kg}^{-1}$ dry soil. This $\mathrm{N}$ rate corresponded approximately to $300 \mathrm{NO}_{3}{ }^{-} \mathrm{-N} \mathrm{kg}$ $\mathrm{ha}^{-1}$ (calculated on $20 \mathrm{~cm}$ layer basis). The soil/water ratio was $1: 1(\mathrm{w} / \mathrm{w})$. There was about $0.5 \mathrm{~cm}$ of stagnant water on soil surface. The vessels with suspensions were tightly sealed with rubber stoppers and incubated in the atmosphere diluted with gaseous nitrogen in order to simulate the lower oxygen content in soil air as compared to the atmospheric one, and giving the opportunity to initiate dissimilative nitrate reduction. The initial concentration of $\mathrm{O}_{2}$ in the gas headspace at the beginning of the incubation was $10 \% \mathrm{v} / \mathrm{v} \pm 0.5$ ( $50 \%$ of the volume of soil headspace was replaced by $\mathrm{N}_{2}$ ). Paraffin films were used on the stoppers to ensure hermetic seals. The headspace gas was sampled through the stopper with a gas - tight syringe. The Eutric Cambisols were incubated at $20^{\circ} \mathrm{C}$ for $21-34$ days without acetylene block (Włodarczyk et al., 2005). The incubation was finished before the 34th day if nitrous oxide was exhausted earlier.

A set of 33 incubation vessels was prepared for each the Eutric Cambisol. Three vessels of these were used for the determination of gas concentration. The other vessels were opened in three replications successively during each measurement day (after 1, 2, 3, 7, 10, 14, 21, 28, 32 and 34 days of incubation) for determination of $\mathrm{pH}$ and nitrate concentration in the suspension.

After opening of the vessels and the measurements of $\mathrm{pH}$ (with pH- meter, Radiometer, Copenhagen) the soil suspensions were quantitatively transferred into plastics flasks, shaken for $1 \mathrm{~h}$ with $250 \mathrm{ml}$ of $0.01 \mathrm{M} \mathrm{CaCl}_{2}$, and filtered through filter paper for nitrate determination (FIA Star 5000 autoanalyzer FOSS, Tecator) as described previously (Włodarczyk et al., 2005). The determination of $\mathrm{C}_{\text {org. }}$ in the soil samples was based on the reduction of the $\mathrm{Cr}_{2} \mathrm{O}_{7}{ }^{2-}$ ion by organic matter, wherein the unreduced excess $\mathrm{Cr}_{2} \mathrm{O}_{7}{ }^{2-}$ was measured by titration (Balashov et al., 2010).

During the measurement days, the concentration of $\mathrm{N}_{2} \mathrm{O}$ in the headspace gas was determined with a gas chromatograph (Shimadzu GC-14, Japan) equipped with an electron capture detector at $300^{\circ} \mathrm{C}$. The gas components were

T a b l e 1. Basic properties of the Eutric Cambisols under investigation (modified table of Włodarczyk et al., 2005)

\begin{tabular}{|c|c|c|c|c|c|c|c|}
\hline \multirow{2}{*}{$\begin{array}{l}\text { Parent } \\
\text { material }\end{array}$} & \multirow{2}{*}{ Soil No. } & \multicolumn{3}{|c|}{ Particle size fraction $(\%)$} & \multirow{2}{*}{$\begin{array}{l}\mathrm{C}_{\text {org. }} \\
(\%)\end{array}$} & \multirow{2}{*}{$\begin{array}{l}\mathrm{NO}_{3}-\mathrm{N}_{0} * \\
\left(\mathrm{mg} \mathrm{kg}^{-1}\right)\end{array}$} & \multirow{2}{*}{$\begin{array}{c}\mathrm{pH}_{0} * \\
\text { in } \mathrm{KCl}\end{array}$} \\
\hline & & $>0.05 \mathrm{~mm}$ & $0.05-0.002 \mathrm{~mm}$ & $<0.002 \mathrm{~mm}$ & & & \\
\hline \multirow{4}{*}{ Sand } & 1 & 95 & 5 & 0 & 0.67 & 4.53 & 4.69 \\
\hline & 2 & 78 & 22 & 0 & 0.92 & 58.2 & 4.95 \\
\hline & 3 & 85 & 12 & 3 & 0.32 & 6.47 & 7.35 \\
\hline & 4 & 74 & 21 & 5 & 0.44 & 29.94 & 7.38 \\
\hline \multirow{3}{*}{ Silt } & 5 & 52 & 43 & 5 & 2.31 & 32.93 & 5.37 \\
\hline & 6 & 32 & 60 & 8 & 2.85 & 65.76 & 3.94 \\
\hline & 7 & 27 & 67 & 6 & 1.24 & 7.87 & 4.71 \\
\hline \multirow{4}{*}{ Loam } & 8 & 63 & 23 & 14 & 0.77 & 9.46 & 6.85 \\
\hline & 9 & 71 & 21 & 8 & 0.57 & 17.88 & 7.61 \\
\hline & 10 & 69 & 28 & 3 & 0.88 & 9.78 & 5.56 \\
\hline & 11 & 55 & 41 & 4 & 1.89 & 5.37 & 3.83 \\
\hline
\end{tabular}

*Values at the start of incubation. 
separated on a column ( $2 \mathrm{~m}$ long) packed with a Porapak Q and maintained at $80^{\circ} \mathrm{C}$. The carrier gas was He flowing at a rate of $40 \mathrm{ml} \mathrm{min}$. The temperature of injector was $120^{\circ} \mathrm{C}$. The contents of $\mathrm{N}_{2} \mathrm{O}-\mathrm{N}$ were corrected for gas dissolved in the water using literature values of Bunsen absorption coefficient $(\alpha)$ of 0.629 at $20^{\circ} \mathrm{C}$ (Gliński and Stępniewski, 1985).

As the nitrous oxide content in the headspace showed an initial phase of increase and, after reaching a maximum it started to decrease, the results related to the denitrification of nitrate to $\mathrm{N}_{2} \mathrm{O}$ were expressed as:

- maximum cumulative $\mathrm{N}_{2} \mathrm{O}$ efflux $\left(\max \mathrm{N}_{2} \mathrm{Oe}\right)$,

- an average daily $\mathrm{N}_{2} \mathrm{O}$ efflux $\left(\mathrm{aN}_{2} \mathrm{Oe}\right)$,

- the highest daily $\mathrm{N}_{2} \mathrm{O}$ efflux $\left(\mathrm{hN}_{2} \mathrm{Oe}\right)$, whereas the results related to $\mathrm{N}_{2} \mathrm{O}$ consumption phase were expressed as:

- total $\mathrm{N}_{2} \mathrm{O}$ consumption $\left(\mathrm{N}_{2} \mathrm{Oc}\right)$,

- an average daily $\mathrm{N}_{2} \mathrm{O}$ consumption $\left(\mathrm{aN}_{2} \mathrm{Oc}\right)$, and

- the highest daily $\mathrm{N}_{2} \mathrm{O}$ consumption $\left(\mathrm{hN}_{2} \mathrm{Oc}\right)$.

The interrelations between efflux and consumption were analyzed in terms of the ratio of $\mathrm{N}_{2} \mathrm{O}$ emission to $\mathrm{N}_{2} \mathrm{O}$ consumption (e/c ratio) for an average and highest daily effluxes to an average and highest daily consumption (ae/ac ratio and he/hc ratio). Moreover the total nitrate (native + added) reduced $\left(\mathrm{NO}_{3}-\mathrm{R}\right)$ and denitrified do $\mathrm{N}_{2} \mathrm{O}\left(\mathrm{NO}_{3}-\mathrm{D}\right)$ were calculated.

The average daily efflux $\left(\mathrm{aN}_{2} \mathrm{Oe}\right)$ was calculated by considering the maximal cumulative $\mathrm{N}_{2} \mathrm{O}$ content in the headspace divided by the length of the emission period. The average daily consumption $\left(\mathrm{aN}_{2} \mathrm{Oc}\right)$ was calculated by considering $\mathrm{N}_{2} \mathrm{O}$ drop in the headspace (after its maximum content) to the end of incubation divided by the length of this period. The ratio of $\mathrm{N}_{2} \mathrm{O}$ emission to $\mathrm{N}_{2} \mathrm{O}$ consumption (e/c ratio) was calculated by division the average (or highest) daily effluxes by average (or highest) daily consumption (ae/ac and he/hc).

The linear, multiplicative, exponential or logarithmic models were used in the regression analysis, and in each case the model with the highest $\mathrm{R}^{2}$ was selected as the best fit for the experimental data (Statgraphics 5.0).

\section{RESULTS AND DISSCUSION}

The changes of $\mathrm{NO}_{3}$, and $\mathrm{N}_{2} \mathrm{O}$ concentrations during incubation of the Eutric Cambisols developed from sand, silt and loam under soil hypoxia and nitrate treatment are shown in Figs 1-3. The Eutric Cambisols under consideration showed a high variability of all the investigated features. Calculated values varied among the Eutric Cambisols developed from the same and different parent materials. The investigated soils were characterized by a very large variation of original nitrate content. The reasons for this may be numerous. For example, the lower nitrate content in the heavy textured soils (loams) may be associated with a prevalence of denitrification over nitrification. In the light textured soils we can observed the opposite situation.
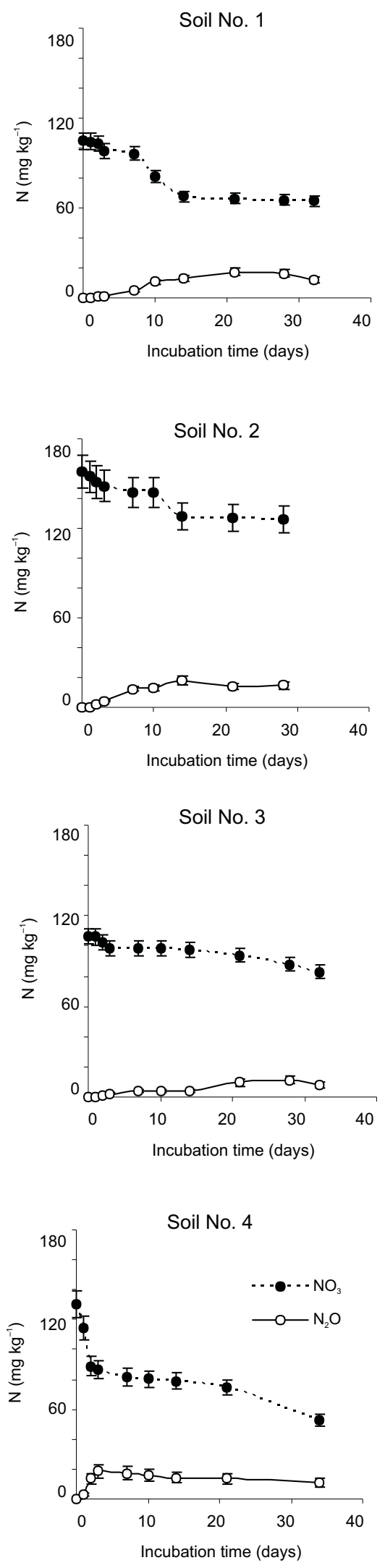

Fig. 1. Cumulative curves $\mathrm{N}_{2} \mathrm{O}$ efflux and nitrate concentration in the Eutric Cambisols developed from sand. 
Some authors concluded that denitrifying bacteria show a lack of certain reductases in the reductive pathways. In this case, the lack of nitrate reductase may lead to accumulation of nitrates. Frequently missing enzymes in this pathway are nitrate and nitrous oxide reductases (Robertson and Kuenen, 1991). However Klemedtson and Svensson (1988) paying attention to the phenomenon say that not all bacteria have a set of enzymes capable to convert nitrates to molecular nitrogen, $\mathrm{N}_{2} \mathrm{O}$ is sometimes the main product, while others start from the reduction of nitrite rather than nitrate. All these factors may affect the nitrate content of the Eutric Cambisols in greater or lesser extent.
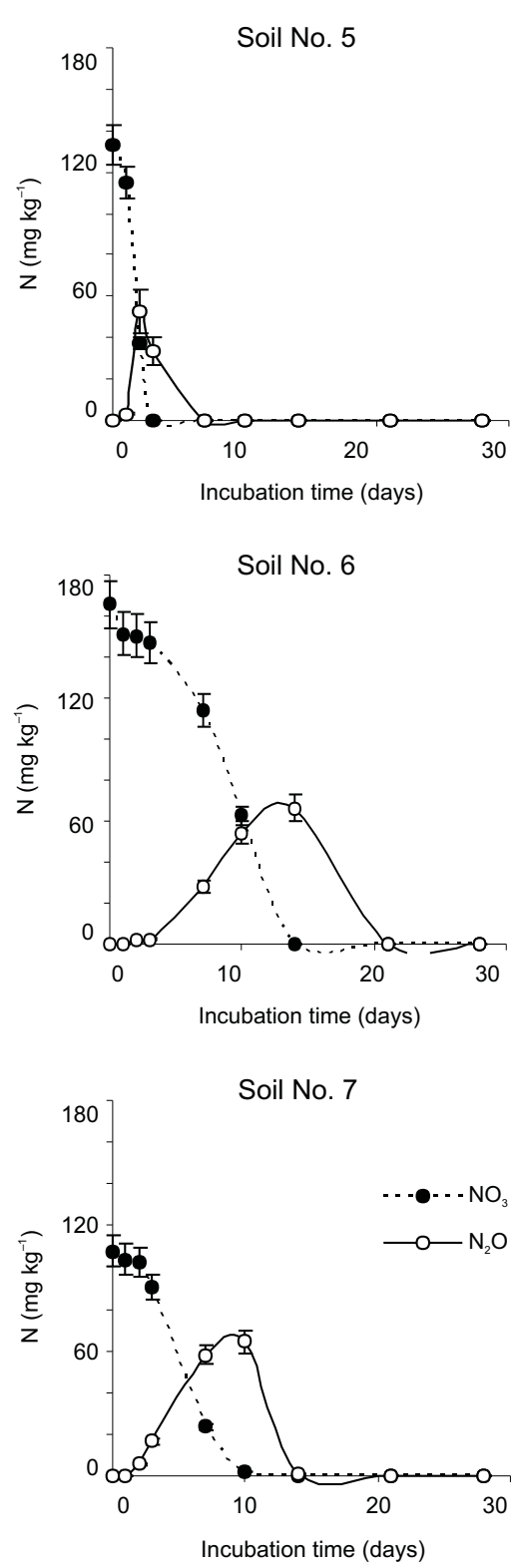

Fig. 2. Cumulative curves $\mathrm{N}_{2} \mathrm{O}$ efflux and nitrate concentration in the Eutric Cambisols developed from silt.
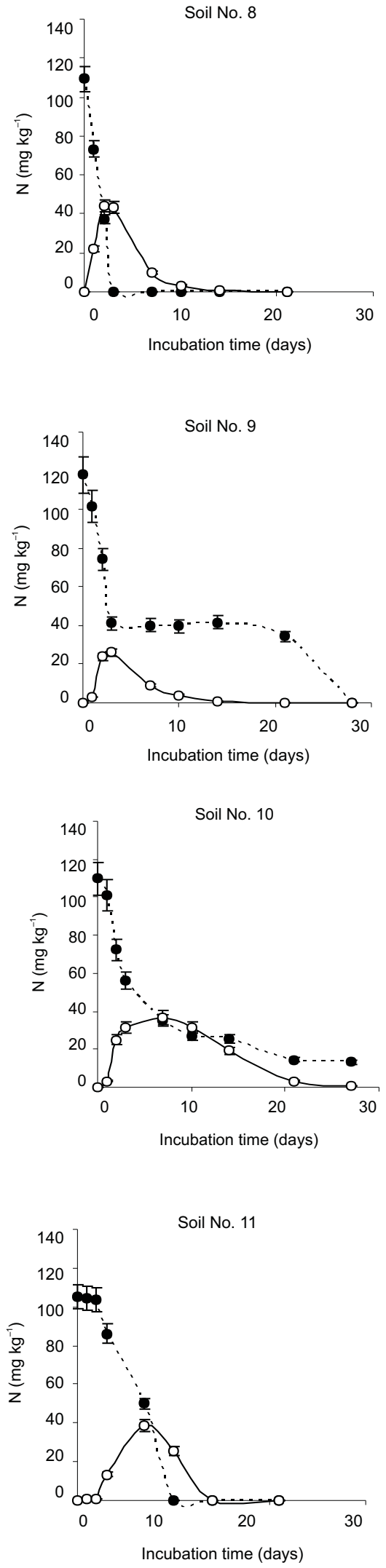

Fig. 3. Cumulative curves $\mathrm{N}_{2} \mathrm{O}$ efflux and nitrate concentration in the Eutric Cambisols developed from loam. 
The highest $\mathrm{NO}_{3}-\mathrm{R}$ was found in the soils developed from silt, lower activity in the soils developed from loam, and the lowest one in the soils developed from sand. The percentage of $\mathrm{NO}_{3}-\mathrm{R}$ (Table 2) differed especially among the soils developed from sand (35\%) and those developed from both from loam $(97 \%)$ and silt (100\%). Such a large difference in the reduction of nitrate between the Eutric Cambisols developed from sand and developed from silt may be caused by the oxygenation status under natural conditions before sampling. In other words, the history of the soil before it is sampled is very important (Włodarczyk, 2000).

Another inhibitory factor the process of nitrate reduction can also be deficiency of ammonia form in the soils studied. Denitrifying bacteria cannot use nitrate as a nitrogen source and require ammonia form. Moreover the investigated soils were characterized by large variations in $\mathrm{C}_{\text {org. }}$. content, which had a definite influence on the amount of nitrate reduction.

Nitrate denitrified to $\mathrm{N}_{2} \mathrm{O}\left(\mathrm{NO}_{3}-\mathrm{D}\right)$ was calculated in two ways (Table 2). In the first one the nitrate denitrified to $\mathrm{N}_{2} \mathrm{O}$ form $\left(\mathrm{NO}_{3}\right.$-D) was expressed as percentage of total initial nitrate content. It varied for particular Eutric Cambisols between 11 and $60 \%$. The highest percentage of $\mathrm{NO}_{3}-\mathrm{D}$ was observed in the soils developed from silt $(46 \%$ in ave- rage), 1.4 times lower value was observed in the case of soils developed from loam (33\% in average) and 3.5 times lower in soils developed from sand (13\% in average).

In the second way the amount of nitrate denitrified to $\mathrm{N}_{2} \mathrm{O}$ form $\left(\mathrm{NO}_{3}-\mathrm{D}\right)$ was calculated as percentage of the total nitrate reduced and resulted in 22 to $60 \%$ as the percentage of nitrous oxide in the reduced nitrate (Table 2). The highest percentage of $\mathrm{NO}_{3}$-D was observed in the soils developed from silt (46\% in average), nearly the same value was observed in the case of soils developed form sand (43\% in average), and 1.3 times lower value occurred in soils developed from loam (34\% in average).

The first way of calculating the loss of nitrate informs us of the total losses of $\mathrm{NO}_{3}{ }^{-}$in the Eutric Cambisols. It is a very important information from the agricultural point of view. Under flooding conditions the microorganisms compete with the plants for nitrates.

The second way of calculating the losses of nitrate informs us of the conversion of $\mathrm{NO}_{3}{ }^{-}$to the form of nitrous oxide. In turn, this information is extremely important from the standpoint of natural environment protection. As it is clear from this data the ability to release $\mathrm{N}_{2} \mathrm{O}$ in the Eutric Cambisols is similar in soils with coarser particles (sand and silt) than in the loams. Soils of coarser grain-size distribution

T a b l e 2. $\mathrm{NO}_{3}-\mathrm{N}$ reduced $\left(\mathrm{NO}_{3}-\mathrm{R}\right)$ and denitrified $\left(\mathrm{NO}_{3}-\mathrm{D}\right)$ for the investigated Eutric Cambisols

\begin{tabular}{|c|c|c|c|c|c|}
\hline \multirow{5}{*}{ Parent material } & \multirow{5}{*}{ Soil No. } & \multicolumn{4}{|c|}{$\mathrm{NO}_{3}-\mathrm{N}$} \\
\hline & & \multicolumn{2}{|c|}{ Reduced } & \multirow{2}{*}{\multicolumn{2}{|c|}{$\begin{array}{c}\text { Reduced to } \mathrm{N}_{2} \mathrm{O} \text { form }\left(\mathrm{NO}_{3}-\mathrm{D}\right) \\
\text { Calculated with respect to }\end{array}$}} \\
\hline & & \multirow{2}{*}{\multicolumn{2}{|c|}{ Total $\left(\mathrm{NO}_{3}-\mathrm{R}\right)$}} & & \\
\hline & & & & total $\mathrm{NO}_{3}^{-}$ & reduced $\mathrm{NO}_{3}^{-}$ \\
\hline & & $\left(\mathrm{mg} \mathrm{kg}^{-1}\right)$ & $(\%)^{*}$ & $(\%)^{* *}$ & $(\%)^{* * *}$ \\
\hline \multirow{4}{*}{ Sand } & 1 & 39.9 & 36.5 & 16.5 & 43.3 \\
\hline & 2 & 31.9 & 20.2 & 11.3 & 55.9 \\
\hline & 3 & 23.6 & 22.1 & 10.7 & 48.4 \\
\hline & 4 & 77.2 & 59.4 & 14.2 & 23.8 \\
\hline \multirow[t]{2}{*}{ Average } & & 43.2 & 34.6 & 13.2 & 42.8 \\
\hline & 5 & 132.9 & 100 & 39.3 & 39.3 \\
\hline \multirow[t]{2}{*}{ Silt } & 6 & 165.8 & 100 & 40.1 & 40.1 \\
\hline & 7 & 107.9 & 100 & 59.5 & 59.5 \\
\hline \multirow[t]{2}{*}{ Average } & & 135.5 & 100 & 46.3 & 46.3 \\
\hline & 8 & 109.5 & 100 & 40.5 & 40.5 \\
\hline \multirow{3}{*}{ Loam } & 9 & 117.9 & 100 & 22.1 & 22.1 \\
\hline & 10 & 96.5 & 86.4 & 33.5 & 38.1 \\
\hline & 11 & 105.4 & 100 & 36.7 & 36.7 \\
\hline Average & & 107.3 & 96.6 & 33.2 & 34.4 \\
\hline
\end{tabular}

*Percent of nitrate reduced $\left(\mathrm{NO}_{3}-\mathrm{R}\right)$ was calculated by considering the decrease of the total nitrate concentration (native + added). **Percent of nitrate denitrified to $\mathrm{N}_{2} \mathrm{O}$ form $\left(\mathrm{NO}_{3}-\mathrm{D}\right.$ ) was calculated to total nitrate concentration (native + added). ***Percent of nitrate denitrified to $\mathrm{N}_{2} \mathrm{O}$ form $\left(\mathrm{NO}_{3}\right.$-D) was calculated to reduced nitrate 
under natural conditions are better aerated. Easier access of oxygen causes that the denitrification process is interrupted at the level of $\mathrm{N}_{2} \mathrm{O}$ because nitrous oxide reductase is particularly sensitive to the presence of oxygen. These soils may be dominated by bacteria not adapted to full denitrification. This ability is the result of influence of various factors under natural conditions, including soil type, which are revealed after flooding of the air-dry soil.

Under the experimental conditions, the highest $\mathrm{N}_{2} \mathrm{O}$ efflux was observed from the soils developed from silt and the lowest one from the soil developed from sand (Figs 1-3). The value of maximum cumulative $\mathrm{N}_{2} \mathrm{O}$ efflux $\left(\max \mathrm{N}_{2} \mathrm{Oe}\right)$ ranged between 11.4 and $66.5 \mathrm{mg} \mathrm{N}_{2} \mathrm{O}-\mathrm{N} \mathrm{kg}^{-1}$ and was observed between 2 nd and 28th day of the experiment (Table 3 ). Silva et al. (2008) investigated nitrous oxide production in sieved air-dried sandy loam soil under $100 \%$ WHC (water holding capacity) and found maximum production about $1 \mathrm{mg}$ $\mathrm{N}_{2} \mathrm{O}-\mathrm{N} \mathrm{kg}^{-1}$ in unamended and about $1.5 \mathrm{mg} \mathrm{N}_{2} \mathrm{O}-\mathrm{N} \mathrm{kg}^{-1}$ in
$\mathrm{NH}_{4}{ }^{+}$amended soil after first day of incubation. Deyan and Changchum (2010) investigated $\mathrm{N}_{2} \mathrm{O}$ emission from sieved fresh and amended with ammonium nitrate $\left(5 \mathrm{mg} \mathrm{N} \mathrm{g}^{-1}\right.$ soil $)$ meadow soil. Cumulative $\mathrm{N}_{2} \mathrm{O}$ emission was equal $41.86 \mathrm{mg}$ $\mathrm{N} \mathrm{kg}^{-1}$ from soil after the 65-day of incubation. Yanai et al. (2008) studied nitrous oxide production in sieved fresh and amended with $\mathrm{KNO}_{3}\left(8 \mathrm{~g}^{-1}\right)$ grassland fields under flooded conditions. The examples of production and $\mathrm{N}_{2} \mathrm{O}$ emissions show enormous adaptability of soil microorganisms to the extremely different soil moisture conditions.

The average daily $\mathrm{N}_{2} \mathrm{O}$ efflux $\left(\mathrm{aN}_{2} \mathrm{Oe}\right)$, ranged between 0.4 to $26.1 \mathrm{mg} \mathrm{N} \mathrm{kg}^{-1} \mathrm{~d}^{-1}$. The $\mathrm{aN}_{2} \mathrm{Oe}$ was lowest in the sandy soils and the highest in the soils developed from silt .

The highest daily $\mathrm{N}_{2} \mathrm{O}$ efflux $\left(\mathrm{hN}_{2} \mathrm{Oe}\right)$ ranged between 1.8 and $24.5 \mathrm{mg} \mathrm{N} \mathrm{kg}^{-1} \mathrm{~d}^{-1}$ and reached maximum values in the soils developed from loam while the lowest ones were observed in the sandy soils (Table 3 ). The $\mathrm{hN}_{2} \mathrm{Oe}$ showed a large variation among the Eutric Cambisols.

T a b l e 3. $\mathrm{N}_{2} \mathrm{O}$ efflux and consumption for the investigated Eutric Cambisols

\begin{tabular}{|c|c|c|c|c|c|c|c|c|c|c|}
\hline \multirow{4}{*}{$\begin{array}{l}\text { Parent } \\
\text { material }\end{array}$} & \multirow{4}{*}{ Soil No. } & \multicolumn{9}{|c|}{$\mathrm{N}_{2} \mathrm{O}-\mathrm{N}$} \\
\hline & & \multicolumn{3}{|c|}{ Efflux } & \multicolumn{4}{|c|}{ Consumption } & \multirow{3}{*}{$\begin{array}{c}\mathrm{ae} / \mathrm{ac} \\
* * * * *\end{array}$} & \multirow{3}{*}{$\begin{array}{c}\text { he/hc } \\
* * * * * *\end{array}$} \\
\hline & & $\begin{array}{c}\text { Total } \\
\left(\mathrm{NO}_{3}-\mathrm{D}\right)\end{array}$ & $\begin{array}{c}\text { Average } \\
\text { daily* } \\
\left(\mathrm{aN}_{2} \mathrm{Oe}\right)\end{array}$ & $\begin{array}{l}\text { Highest } \\
\text { daily** } \\
\left(\mathrm{hN}_{2} \mathrm{Oe}\right)\end{array}$ & $\begin{array}{c}\text { Total } \\
\mathrm{N}_{2} \mathrm{O} \text { form }\end{array}$ & \multirow[t]{2}{*}{$\begin{array}{c}\% \text { of } \\
\text { effluxed }\end{array}$} & $\begin{array}{l}\text { Average } \\
\text { daily*** } \\
\left(\mathrm{aN}_{2} \mathrm{Oc}\right)\end{array}$ & $\begin{array}{c}\text { Highest } \\
\text { daily**** } \\
\left(\mathrm{hN}_{2} \mathrm{Oc}\right) \\
\end{array}$ & & \\
\hline & & $\left(\mathrm{mg} \mathrm{kg}^{-1}\right)$ & \multicolumn{2}{|c|}{$\left(\mathrm{mg} \mathrm{kg}^{-1} \mathrm{~d}^{-1}\right)$} & $\left(\mathrm{mg} \mathrm{kg}^{-1}\right)$ & & \multicolumn{2}{|c|}{$\left(\mathrm{mg} \mathrm{kg}^{-1} \mathrm{~d}^{-1}\right)$} & & \\
\hline \multirow{4}{*}{ Sand } & 1 & 17.3 & 0.8 & 1.9 & 5.2 & 30.0 & 0.5 & 1.1 & 1.6 & 1.7 \\
\hline & 2 & 17.8 & 1.3 & 2.1 & 3.3 & 18.4 & 0.2 & 0.5 & 6.5 & 4.2 \\
\hline & 3 & 11.4 & 0.4 & 1.8 & 3.4 & 30.2 & 0.9 & 0.9 & 0.4 & 2.0 \\
\hline & 4 & 18.4 & 6.1 & 10.4 & 7.3 & 52.9 & 0.3 & 0.5 & 20.3 & 20.8 \\
\hline \multirow[t]{2}{*}{ Average } & & 16.2 & 2.2 & 4.1 & 4.8 & 32.9 & 0.5 & 0.8 & 7.2 & 7.2 \\
\hline & 5 & 52.3 & 26.1 & 24.5 & 52.3 & 100 & 2.8 & 18.7 & 9.3 & 1.3 \\
\hline \multirow[t]{2}{*}{ Silt } & 6 & 66.5 & 4.8 & 8.7 & 66.5 & 100 & 9.5 & 9.5 & 0.5 & 0.9 \\
\hline & 7 & 64.1 & 6.1 & 11.1 & 64.1 & 100 & 3.1 & 15.7 & 2.0 & 0.7 \\
\hline \multirow[t]{2}{*}{ Average } & & 61.0 & 12.3 & 14.8 & 61.0 & 100 & 5.1 & 14.6 & 3.9 & 1.0 \\
\hline & 8 & 44.3 & 22.2 & 22.2 & 43.9 & 99.2 & 2.3 & 8.4 & 9.7 & 2.6 \\
\hline \multirow{3}{*}{ Loam } & 9 & 26.0 & 8.7 & 20.9 & 25.9 & 99.3 & 1.0 & 4.2 & 8.7 & 5.0 \\
\hline & 10 & 36.7 & 5.3 & 21.8 & 36.2 & 98.4 & 1.8 & 3.1 & 2.9 & 7.0 \\
\hline & 11 & 38.7 & 5.5 & 12.2 & 38.7 & 100 & 2.8 & 6.4 & 2.0 & 1.9 \\
\hline Average & & 36.4 & 10.4 & 19.3 & 36.2 & 99.2 & 2.0 & 5.5 & 5.8 & 4.1 \\
\hline
\end{tabular}

*The average daily efflux was calculated by considering the total cumulative $\mathrm{N}_{2} \mathrm{O}$ increase in the headspace divided by the length of this period. **The highest rate of daily efflux was calculated by considering the highest rate of cumulative $\mathrm{N}_{2} \mathrm{O}$ increase in the headspace divided by the length of this period. ***The average daily consumption was calculated by considering $\mathrm{N}_{2} \mathrm{O}$ drop in the head space after its maximum content to the end of incubation divided by the length of this period. $* * * *$ The highest rate of daily consumption was calculated by considering $\mathrm{N}_{2} \mathrm{O}$ drop in the head space after its maximum content to the day of highest rate of $\mathrm{N}_{2} \mathrm{O}$ consumption divided by the length of this period. $* * * * * \mathrm{aN}_{2} \mathrm{Oe} / \mathrm{aN}_{2} \mathrm{Oc}-$ daily average efflux/daily average consumption, $* * * * * * \mathrm{hN}_{2} \mathrm{Oe} / \mathrm{hN}_{2} \mathrm{Oc}-$ highest daily average efflux/highest daily average consumption. 
Four Eutric Cambisols: one silty (No. 5) and three loamy (Nos 8, 9 and 10) were very active in $\mathrm{N}_{2} \mathrm{O}$ release, their $\mathrm{hN}_{2} \mathrm{Oe}$ was more than $20 \mathrm{mg} \mathrm{N} \mathrm{N}_{2} \mathrm{O}-\mathrm{N} \mathrm{kg}^{-1} \mathrm{~d}^{-1}$. These four Eutric Cambisols reached maximum daily nitrous oxide efflux during first two days. These four soils showed the best adaptation to the conditions of limited access of oxygen, when some kind of bacteria change aerobic respiration to nitrate. In these four soils we observed the phenomenon of rapid adaptation of microorganisms to changes in electron acceptor and nitrate reductase synthesis. This is undoubtedly a result of adaptation to natural conditions, forced by the state of oxygenation, especially in the case of loamy soils. Blaszczyk (1992) by examining the activity of denitrifying, 2 strains of Pseudomonas and one strain of the genus Paracoccus in cultures with the addition of $\mathrm{NO}_{3}$ and $\mathrm{NO}_{2}$ found that the bacteria need time for the synthesis and activation of nitrite reductase by changing the electron acceptor. Simultaneous incubation of these strains in the substrate with the addition of nitrate and nitrite showed three different induction systems reductases: nitrate and nitrite.

Cumulative $\mathrm{N}_{2} \mathrm{O}$ curves show an increase in the initial period and then, after maximum, a decrease as a result of nitrous oxide consumption (Figs 1-3). The longest period till the start of nitrous oxide consumption was 28 days for the soil developed from sand (No. 3), while the shortest (2 days) for one soil developed from silt (No. 5) and one soil developed from loam (No. 8). Time needed for beginning of $\mathrm{N}_{2} \mathrm{O}$ consumption was longest for soils developed from sand (3-28 days), then for soils developed from silt (2-14 days), and the shortest one for the loamy soils (2-7 days).

The Eutric Cambisols under study were characterized by different ability to nitrous oxide consumption $\left(\mathrm{N}_{2} \mathrm{Oc}\right)$. The soils developed from silt consumed all the produced $\mathrm{N}_{2} \mathrm{O}(100 \%)$, loamy soils consumed almost all produced nitrous oxide (99.2\%), and sandy soils consumed only $32.9 \%$ of the $\mathrm{N}_{2} \mathrm{O}$ produced. The average values of the total nitrous oxide consumption ranged between $4.8-61.0 \mathrm{mg} \mathrm{N} \mathrm{kg}^{-1}$ for the investigated groups (Table 3 ).

The average $\mathrm{N}_{2} \mathrm{O}$ consumption $\left(\mathrm{aN}_{2} \mathrm{Oc}\right)$ ranged between 0.2 to $9.5 \mathrm{mg} \mathrm{N} \mathrm{kg}^{-1} \mathrm{~d}^{-1}$ and was much lower than the highest $\mathrm{N}_{2} \mathrm{O}$ consumption $\left(\mathrm{hN}_{2} \mathrm{Oc}\right)$, especially in the silty and loamy soils (Table 3). The $\mathrm{aN}_{2} \mathrm{Oc}$ was lowest in sandy soils, but the highest one in silty ones.

The average $\mathrm{hN}_{2} \mathrm{Oc}$ ranged between $0.8-14.6 \mathrm{mg} \mathrm{N}$ $\mathrm{kg}^{-1} \mathrm{~d}^{-1}$ and was highest in the soils developed from silt. Two silty soils (Nos 5 and 7) were very active in $\mathrm{N}_{2} \mathrm{O}$ consumption. Their daily $\mathrm{N}_{2} \mathrm{O}$ consumption was more than $15 \mathrm{mg}$ $\mathrm{N} \mathrm{kg}^{-1}$ (Table 3).

The relationships presented in Fig. 4 show that max $\mathrm{N}_{2} \mathrm{Oe}$ was strongly negatively correlated with the sand fraction content $\left(\mathrm{R}^{2}=0.8928\right)$ and positively correlated with finer grain size fractions ie with silt $\left(\mathrm{R}^{2}=0.8366\right)$ and weekly with clay $\left(\mathrm{R}^{2}=0.2933\right.$, not shown). The values of average nitrous oxide consumption $\left(\mathrm{aN}_{2} \mathrm{Oc}\right)$ are also negatively correlated with sand fraction and positively with the silt and clay fraction (clay fraction not shown in Fig. 5). Both maximum cumulative efflux of nitrous oxide and average consumption are positively correlated with the $\mathrm{C}_{\mathrm{org}}$. Of special interest is Fig. 6 presenting highly positive correlation $\left(\mathrm{R}^{2}=\right.$ 0.9759 ) between efflux of nitrous oxide and its consumption.

Incubation of nitrate amended Eutric Cambisols under hypoxia gave under laboratory conditions $16.2 \mathrm{mg} \mathrm{N} \mathrm{kg}^{-1}$, 61.0 and $36.4 \mathrm{mg} \mathrm{N} \mathrm{kg}^{-1}$ losses of nitrogen through denitrification to $\mathrm{N}_{2} \mathrm{O}$ for the soils developed from sands, silts and loams, respectively (Table 3 ). This indicates that about 13 , 46 , and $33 \%$ of initial nitrate content was reduced to $\mathrm{N}_{2} \mathrm{O}$ in the sandy, silty and loamy Eutric Cambisols, respectively. However, total nitrate- $\mathrm{N}$ decrease $\left(\mathrm{NO}_{3}-\mathrm{R}\right)$ comprising reduction to $\mathrm{N}_{2} \mathrm{O}, \mathrm{N}_{2}$, and $\mathrm{NH}_{4}{ }^{+}$and other products including $\mathrm{N}$ incorporated into biomass was $43.2,135.5$, and $107.3 \mathrm{mg}$ $\mathrm{N} \mathrm{kg}^{-1}$ for the Eutric Cambisols developed from sand, silt and loam, respectively (Table 2). Matthews et al. (2010) showed that the main soil property influencing $\mathrm{N}_{2} \mathrm{O}$ fluxes was nitrate concentration. Vilain et al. (2010) found that nitrous oxide was significantly correlated with the highest range of $\mathrm{NO}_{3}{ }^{-}$content in soils, but no relationship with the lowest range of $\mathrm{NO}_{3}{ }^{-}$content.
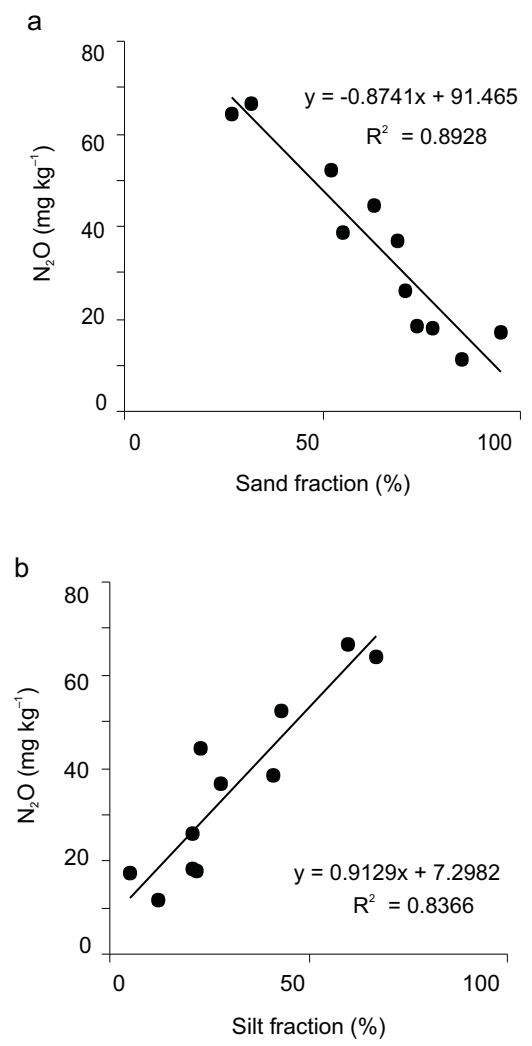

Fig. 4. Maximum cumulative $\mathrm{N}_{2} \mathrm{O}$ efflux as a function of the particle size fractions: $\mathrm{a}$ - sand fraction, $\mathrm{b}$ - silt fraction (modified figure of Włodarczyk et al., 2005). 
Taking into consideration the maximum of cumulative nitrous oxide efflux and its average daily consumption, the investigated Eutric Cambisols were divided as follows: - 'weak emitter' - efflux below $20 \mathrm{mg} \mathrm{N}_{2} \mathrm{O}-\mathrm{N} \mathrm{kg}^{-1}$; - 'good emitter' - 20 to $40 \mathrm{mg} \mathrm{N} \mathrm{N}_{2} \mathrm{O}-\mathrm{N} \mathrm{kg}^{-1}$;

- 'very good emitter' - more than $40 \mathrm{mg} \mathrm{N}_{2} \mathrm{O}-\mathrm{N} \mathrm{kg}^{-1}$;

- 'weak consumer' - absorbed below $1 \mathrm{mg} \mathrm{N}_{2} \mathrm{O}-\mathrm{N} \mathrm{kg}^{-1} \mathrm{~d}^{-1}$;

- 'good consumer' - 1 to $5 \mathrm{mg} \mathrm{N} \mathrm{N}_{2} \mathrm{O}-\mathrm{N} \mathrm{kg}^{-1} \mathrm{~d}^{-1}$;

- 'very good consumer' - more than $5 \mathrm{mg} \mathrm{N}_{2} \mathrm{O}-\mathrm{N} \mathrm{kg}^{-1} \mathrm{~d}^{-1}$.
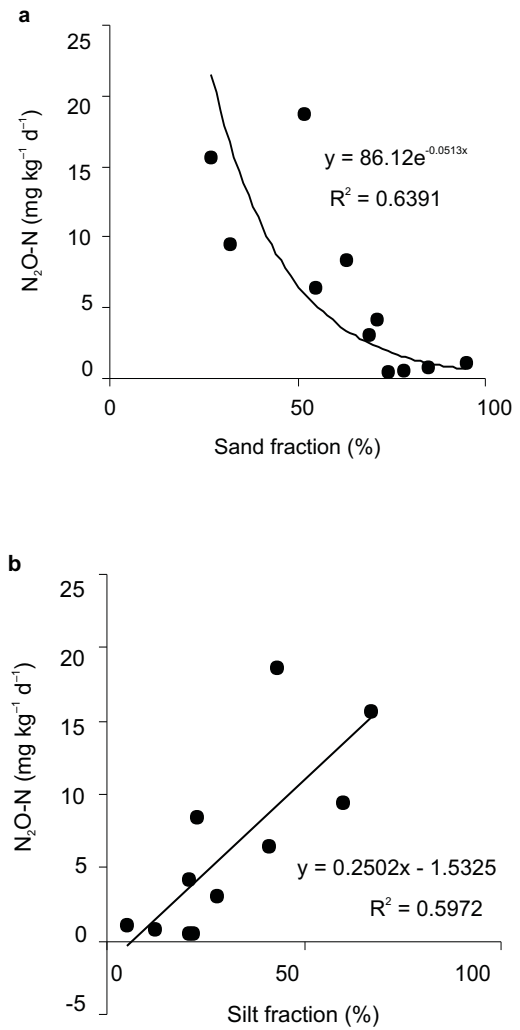

Fig. 5. Average daily $\mathrm{N}_{2} \mathrm{O}$ consumption as a function of the particle size fractions: $\mathrm{a}-$ sand fraction, $\mathrm{b}$ - silt fraction and (modified figure of Włodarczyk et al., 2005).

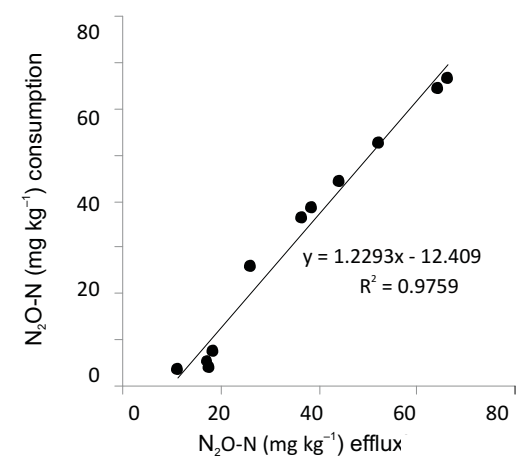

Fig. 6. Maximum $\mathrm{N}_{2} \mathrm{O}$ consumption versus maximum cumulative $\mathrm{N}_{2} \mathrm{O}$ efflux.
According to this, the Eutric Cambisols were divided into four groups (Table 4):

- 'weak emitter' and 'weak consumer', inside this group were all soils developed from sand (Nos 1-4),

- 'good emitter' and 'good consumer', which represent loamy soils (Nos 9, 10, 11),

- 'very good emitter' and 'good consumer' - soils No. 8 (loam), 5, 7 (silt), and

- 'very good emitter' and 'very good consumer' - soil No. 6 (silt).

This is the result of the high correlation $\left(R^{2}=0.9759\right)$ between the emission of nitrous oxide and its consumption presented in Fig. 6. This relationship is a very important from the standpoint of environmental protection because of $\mathrm{N}_{2} \mathrm{O}$ has a big impact on the greenhouse effect and ozone layer destruction.

Regression analysis of $\max \mathrm{N}_{2} \mathrm{Oe}$ and $\mathrm{aN}_{2} \mathrm{Oc}$, as a function of granulometric composition showed that the analyzed indexes were closely related to coarser (sand and silt) granulometric soil fractions; negatively only to sand fraction $(>0.05 \mathrm{~mm}, \mathrm{p}<0.001)$ and positively to silt $(0.05-0.002 \mathrm{~mm}$, $\mathrm{p}<0.001)$ and colloidal fraction $(<0.002 \mathrm{~mm}, \mathrm{p}<0.05)$ (Figs 4 and 5). Włodarczyk et al. (2005) investigated 16 soils developed from sand, silt and loam, found very high correlation between granulometric composition and both nitrous oxide efflux and daily nitrous oxide consumption. The authors observed that the total $\mathrm{N}_{2} \mathrm{O}$ evolution and daily nitrous oxide consumption showed a high negative linear correlation with the content of the fraction $>0.05 \mathrm{~mm}$, a positive linear correlation with $0.05-0.002 \mathrm{~mm}$ fraction and the lower one with $<0.002 \mathrm{~mm}$ fraction.

In our opinion, the particle size distribution explains very low $\mathrm{N}_{2} \mathrm{O}$ efflux and consumption from soils developed from sand and much higher from the soil developed from finer fraction (0.005-0.002). Vilain et al. (2010) concluded that nitrous oxide emission from riparian sites depended on particle size, soil type, $\mathrm{N}$ input etc. Water-filled pore space and $\mathrm{NO}_{3}{ }^{-}$soil concentration explained most of the $\mathrm{N}_{2} \mathrm{O}$ flux variability during the entire sampling period. Lamers et al. (2007) showed a large variability between the different soil

T a b l e 4. Eutric Cambisols characteristics in terms of their ability to $\mathrm{N}_{2} \mathrm{O}$ efflux and consumption

\begin{tabular}{|c|c|c|c|c|c|c|c|c|c|c|c|}
\hline \multirow{2}{*}{$\begin{array}{l}\text { Soil } \\
\text { characteristics }\end{array}$} & \multicolumn{4}{|c|}{ Sandy soils } & \multicolumn{3}{|c|}{ Silty soils } & \multicolumn{4}{|c|}{ Loamy soils } \\
\hline & 1 & 2 & 3 & 4 & 5 & 6 & 7 & 8 & 9 & 10 & 11 \\
\hline WE WC & + & + & + & + & & & & & & & \\
\hline GE GC & & & & & & & & & & + & + \\
\hline VGE GC & & & & & + & & + & + & & & \\
\hline VGE VGC & & & & & & + & & & & & \\
\hline
\end{tabular}

WE - weak emitter, GE - good emitter, VGE- very good emitter, WC - weak consumer, GC - good consumer, VGC - very good consumer. 
types in $\mathrm{N}_{2} \mathrm{O}$ fluxes. Data demonstrate that the variability between soil types is mainly driven by the high dynamic water regime at the study site, which causes a highly variable spatial distribution of $\mathrm{N}_{2} \mathrm{O}$ production conditions ranging from optimal to unfavorable. The environment in which denitrifying bacteria are developing, has a significant impact on their selection and activity of denitrifying species. Błaszczyk (1997), Błaszczyk et al. (1985) and Włodarczyk (2000) investigated the seasonal differentiation of dehydrogenase activity of Orthic Luvisol developed from silt and for comparison the same soil samples stored under air-dry conditions for about 7 years. The activity of air-dried soils was higher but the seasonal differentiation remained. It seems that dehydrogenase activity is affected by the environmental properties in the field so strongly that it 'keeps' its initial activity for long time. Measurements of its activity represent immediate metabolic activities of the soil microorganisms at the time of the test. These studies seem to confirm the strong influence of history of the soil on the currently measured soil denitrifying activity. Therefore, in terms of flooding, soil structure is not as significant for denitrification as in conditions of lower humidity, when it decides on the aeration status of the soil.

Closed system incubation gave us the opportunity to compare the capability of soil to nitrous oxide production and then release into the headspace, and its followed consumption. The ratio of 'the average daily effluxes' to 'the average daily consumption' (ae/ac ratio) showed that two Eutric Cambisols (one developed from sand - No. 3 and one developed from silt - No. 6) consumed more $\mathrm{N}_{2} \mathrm{O}$ than released per day (ae/ac ratio $=0.4 / 0.9$ and $4.8 / 9.5 \mathrm{mg} \mathrm{kg}^{-1} \mathrm{~d}^{-1}$ for the soils Nos 3 and 6 , respectively). The highest ae/ac ratio (7.2) was observed in the Eutric Cambisols developed from sand. It means that sandy soils released 7 times more nitrous oxide than consumed per day. Lower ae/ac ratio (5.8) was observed in the loamy soils. The lowest one (3.9) was found in the soils developed from silt. Clough et al. (2006) studied consumption of the ${ }^{15} \mathrm{~N}_{2} \mathrm{O}$ in soil columns filled with sivied silt loam soil (sampled from $0-5 \mathrm{~cm}$ ) via passive diffusion. Investigation showed that nitrous oxide consumption equal to $0.48 \mathrm{ng} \mathrm{N}_{2} \mathrm{O} \mathrm{g}^{-1}$ soil h$^{-1}$.

Considering the relation of the $\mathrm{hN}_{2} \mathrm{Oe}$ and the $\mathrm{hN}_{2} \mathrm{Oc}$ (he/hc ratio) it was shown that two Eutric Cambisols developed from silt (Nos 6 and 7) daily consumed more $\mathrm{N}_{2} \mathrm{O}$, than released $\left(\mathrm{he} / \mathrm{hc}\right.$ ratio $=8.7 / 9.5$ and $11.1 / 15.7 \mathrm{mg} \mathrm{kg}^{-1}$ $\mathrm{d}^{-1}$ ) The highest he/hc ratio (7.2) was observed in the Eutric Cambisols developed from sand. It means that sandy soils released daily 7.2 times more nitrous oxide than consumed per day. About twice lower he/hc ratio (4.1) was observed in the loamy soils. The lowest ratio (1.0) was found in the soils developed from silt. This means that all the produced nitrous oxide by silty soils theoretically may be consumed under field conditions provided that it remains within the gas soil phase or dissolved in soil suspension before it escapes to the atmosphere.
The different $\mathrm{N}_{2} \mathrm{O}$ efflux and its consumption might be due some reasons:

- due to the differences in granulometric composition. In our experiment this effect is visible in all the investigated indexes but especially in he/hc ratio, where the two Eutric Cambisols with the index below one (0.9 and 0.7) are characterized by the highest content of silt fractions among the Eutric Cambisols (Tables 1 and 3). Generally, higher nitrate reduction and $\mathrm{N}_{2} \mathrm{O}$ and consumption was observed in the Eutric Cambisols with higher silt fraction content;

- the results in Figs 7 and 8 points to the significant relationship between total $\mathrm{N}_{2} \mathrm{O}$ efflux, daily $\mathrm{N}_{2} \mathrm{O}$ consumption and $\mathrm{C}_{\text {org. }}$. content;

- under the conditions of incubation experiment, both max $\mathrm{N}_{2} \mathrm{Oe}$ and $\mathrm{hN}_{2} \mathrm{Oc}$ occurred in the wide range of $\mathrm{pH}$ and equaled 4.63-7.23 for $\max _{2} \mathrm{Oe}$ and 4.51-7.60 for $\mathrm{hN}_{2} \mathrm{Oc}$. There were found large differences of $\mathrm{pH}$ values among the Eutric Cambisols developed from sand, silt and loam. The highest $\operatorname{maxN}_{2} \mathrm{Oe}$ was observed at $\mathrm{pH} 6.55$, 5.01 and 7.23 but highest $\mathrm{hN}_{2} \mathrm{Oc}$ was found at $\mathrm{pH} 4.9,5.23$ and 6.5 for the sandy, silty and loamy Eutric Cambisols.

Generally it can be concluded that in the Eutric Cambisols developed from sand and loam the $\mathrm{N}_{2} \mathrm{O}$ efflux occurred at higher $\mathrm{pH}$ values than nitrous oxide consumption. Soil

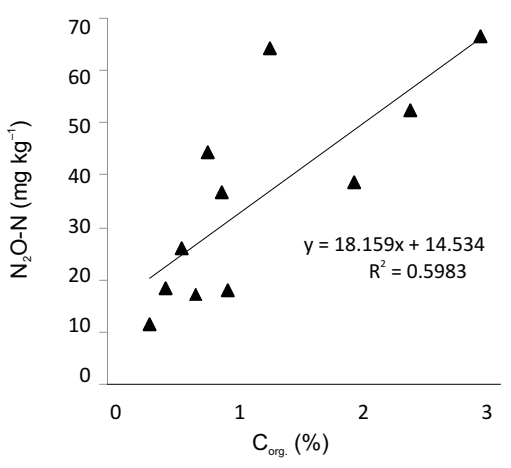

Fig. 7. Maximum cumulative $\mathrm{N}_{2} \mathrm{O}$ efflux as a function of organic carbon content.

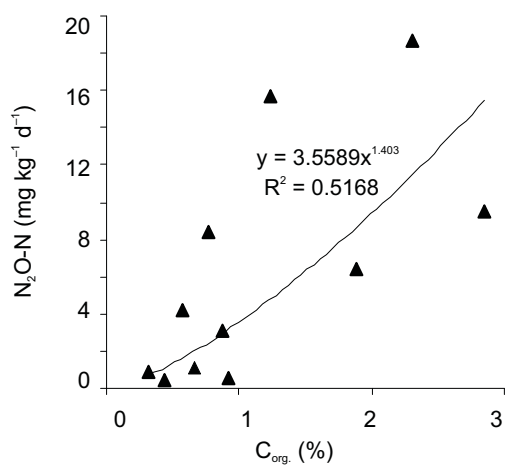

Fig. 8. An average daily $\mathrm{N}_{2} \mathrm{O}$ consumption as a function of organic carbon content. 
reduction processes are accompanied by changes in its $\mathrm{pH}$ towards the neutral. In other words, acidic soil $\mathrm{pH}$ increases while that of alkaline soils decreases (Gliński and Stępniewski, 1985). The increase in $\mathrm{pH}$ of acid soils on submergence is explained by $\mathrm{H}^{+}$uptake in most of the reduction processes. The decrease in $\mathrm{pH}$ of alkaline soils is caused by accumulation of $\mathrm{CO}_{2}$ under anoxia (Ponnameruma, 1972). This phenomenon was also observed during incubation of the studied soils. Soil $\mathrm{pH}$ value for the soil developed from sand and loam was significantly higher (the average $\mathrm{pH}$ value was close to 6) than that of the soils developed from silt (the average $\mathrm{pH}$ value was close to 4.5 at the beginning of incubation). This means that in the case of sandy and loamy soils the $\mathrm{N}_{2} \mathrm{O}$ efflux occurred at the $\mathrm{pH}$ value in the phase of decline but in silty soils in the phase of increasing $\mathrm{pH}$. It seems that nitrous oxide reductase is more sensitive to alkaline environment, then followed by the accumulation of $\mathrm{N}_{2} \mathrm{O}$. Therefore better consumption of $\mathrm{N}_{2} \mathrm{O}$ was observed under slightly acid conditions. The opposite situation was observed in the Eutric Cambisols developed from silt, although the difference in $\mathrm{pH}$ value was small and insignificant.

Taking into consideration all the Eutric Cambisols the highest $\max \mathrm{N}_{2} \mathrm{Oe}$ was observed at $\mathrm{pH} 5.01$ (66.5 $\mathrm{mg} \mathrm{N} \mathrm{kg}^{-1}$ ) but $\mathrm{hN}_{2} \mathrm{Oc}$ at $\mathrm{pH} 5.23\left(18.7 \mathrm{mg} \mathrm{N} \mathrm{kg}^{-1} \mathrm{~d}^{-1}\right.$ ) (data not shown and concern soils developed from silt). It means that there was not found the linear relationship between both max $\mathrm{N}_{2} \mathrm{O}$-e and $\mathrm{hN}_{2} \mathrm{O}$-c and $\mathrm{pH}$ value. Scholefield et al. (1997) showed that denitrification decreased with increasing soil $\mathrm{pH}$ within the range 5.1-9.4. Šimek et al. (2002) found that populations of soil denitrifies might be adopted to prevailing natural soil $\mathrm{pH}$ in the sense that they exhibited the highest denitrifying enzyme activity (DEA) at or near natural $\mathrm{pH}$. If the $\mathrm{pH}$ was artificially changed (either decreased or increased) the DEA was lowered. Some researchers have suggested that soil microbial population dynamics may be more important factor than soil physical and soil chemical factors in explaining the characteristics of nitrous oxide production from soil (Abou-Seada and Ottow, 1985; Granli and Bøckmen, 1994; Pawlson et al., 1988).

\section{CONCLUSIONS}

1. Incubation of nitrate amended the Eutric Cambisols under hypoxic conditions was accompanied by an initial increase of headspace nitrous oxide and after reaching a maximum its subsequent decrease, even at the presence of nitrates.

2 . The appearance of nitrous oxide was observed after 1-3 days and its maximum occurred after 2-28 days from the start of the incubation.

3. Investigated soils were characterized by different native nitrate content and the ability to its reduction. The percentage of nitrate reduced during incubation was: 35, 97 , and $100 \%$ for the Eutric Cambisols developed from sand, loam and silt, respectively.
4. The highest $\mathrm{N}_{2} \mathrm{O}$ efflux was observed from the Eutric Cambisols developed from silt and the lowest from the Eutric Cambisols developed from sand. The value of maximum cumulative $\mathrm{N}_{2} \mathrm{O}$ efflux for particular soils ranged between 11.4-66.5 $\mathrm{mg} \mathrm{N} \mathrm{kg}^{-1}$.

5. The Eutric Cambisols under study were characterized by different ability to nitrous oxide consumption which was $32.9,99.2$, and $100 \%$ of the $\mathrm{N}_{2} \mathrm{O}$ evolved for the sandy, loamy and silty soils, respectively. The average value of nitrous oxide consumption for investigated groups ranged between 4.8-61.0 $\mathrm{mg} \mathrm{N} \mathrm{kg}^{-1}$.

6. The Eutric Cambisols ability to produce nitrous oxide was correlated with its absorption.

7.The Eutric Cambisols capability to generate and to absorb nitrous oxide was correlated negatively with sand content and positively with silt, clay and organic carbon content.

8. Taking into account the soil ability to emission and consumption of nitrous oxide the investigated Eutric Cambisols may be classified as follows: 'weak emitters' and 'weak consumers'; 'good emitters' and 'good consumers'; and 'very good emitters' and 'good consumers'.

9. Three of the tested Eutric Cambisols showed greater activity in consumption of nitrous oxide than in its effluxing.

\section{REFERENCES}

Abou-Seada M.N.I. and Ottow J.G.C., 1985. Effect of increasing oxygen concentration on total denitrification and nitrous oxide release from soil by different bacteria. Biol. Fertil. Soils, 1, 31-38.

Balashov E., Kren J., and Prochazkova B., 2010. Influence of plant residue management on microbial properties and waterstable aggregates of two agricultural soils. Int. Agrophys., 24, 9-13.

Blaszczyk M., 1992. Comparison of denitrification by Paracoccus denitrificans, Pseudomonas stutzeri and Pseudomonas aeruginosa. Acta Microbiol. Polonica, 41(3/4), 203-210.

Blaszczyk M., 1997. Denitrifying sediment bacteria from manmade reservoir of fertiliser nitrogen plant wastewater (RFNPW). Acta Microbiol. Polonica, 46(3), 313-323.

Błaszczyk M., Galka E., Sakowicz E., and Mycielski R., 1985. Denitrification of high concentration of nitrites and nitrates in synthetic medium with different sources of organic carbon III. Methanol. Acta Microbiol. Polonica, 34, 195-206.

Clough T.J., Kelliher F.M., Wang Y.P., and Sherlock R.R., 2006. Diffusion of ${ }^{15} \mathrm{~N}$-labelled $\mathrm{N}_{2} \mathrm{O}$ into soil columns: a promising method to examine the fate of $\mathrm{N}_{2} \mathrm{O}$ in subsoil. Soil Biol. Biochem., (38), 1462-1468.

Deyan L. and Changchun S., 2010. Effects of inorganic nitrogen and phosphorus enrichment on the emission of $\mathrm{N}_{2} \mathrm{O}$ from a freshwater marsh soil in Northeast China. Environ. Earth Sci., 60, 799-807.

Gliński J. and Stępniewski W., 1985. Soil Aeration and its Role for Plants. CRC Press, Boca Raton, FL, USA.

Granli T. and Bøckman O., 1994. Nitrous oxide from agriculture. Norway Agric. Sci. Suppl., 12, 128-129. 
Huang S., Pant H.K., and Lu J., 2007. Effects of water regimes on nitrous oxide emission from soils. Ecol. Eng., 31, 9-15.

Khalil M.A.K., 2000. Special issue: Atmospheric nitrous oxide. Chemosphere - Global Change Sci., 2, 233.

Khalil M.A.K. and Rasmussen R.A., 1992. The global source of nitrous oxide. J. Geophys. Res., 97, 14651-14660.

Klemedtson L. and Svensson B.H., 1988. Effects of acid deposition on denitrification and $\mathrm{N}_{2} \mathrm{O}$ emission from forest soils. In: Critical Loads for Sulphur and Nitrogen. (Eds J. Nilsson, P. Grennfelt), Miljörapport, Copenhagen, Denmark.

Kutilek M. and Nielsen D.R., (Eds) 2010. Facts about Global Warming. Catena Verlag, Reiskirchen, Germany.

Lamers M., Ingwersen J., and Streck T., 2007. Nitrous oxide emissions from mineral and organic soils of a Norway spruce stand in South-West Germany. Atmosph. Environ., 41, 1681-1688.

Li Y.-H., Menviel L., and Peng T-H., 2006. Nitrate deficits by nitrification and denitrification processes in the Indian Ocean. Deep-Sea Res., I, 53, 94-110.

Matthews R.A., Chadwick D.R., Retter A.L., Blackwell M.S.A., and Yamulki S., 2010. Nitrous oxide emissions from smallscale farmland features of UK livestock farming systems. Agric. Ecosys. Environ., 136, 192-198.

Pawlson D.S., Saffigna P.G., and Kragt-Cottar M., 1988. Denitrification at sub-optimal temperatures in soils from different climatic zones. Soil Biol. Biochem., 20, 719-723.

Ponnamperuma F.N., 1972. The chemistry of submerged soils. Adv. Agron., 24, 29-45.

Robertson L.A. and Kuenen J.G., 1991. Physiology of nitrifying and denitrifying bacteria. In: Microbial Production and Consumption of Greenhouse Gases: Methane, Nitrogen Oxides, and Halomethanes (Eds J.E. Rogers, W.B. Whitman). Am. Soc. Microbiol. Press, Washington, DC, USA.

Saggar S., 2010. Estimation of nitrous oxide emission from ecosystems and its mitigation technologies. Agric. Ecosys. Environ., 136, 189-191.
Scholefield D., Hawkins J.M.B., and Jackson S.M., 1997. Use of a flowing helium atmosphere incubation technique to measure the effects of denitrification controls applied to intact cores of a clay soil. Soil Biol. Biochem., 29(9-10), 1337-1344.

Seo D.C. and DeLaune R.D., 2010. Fungal and bacterial mediated denitrification in wetlands: Influence of sediment redox condition. Water Res., 44, 2441-2450.

Silva C.C., Guido M.L., Ceballos J.M., Marsch R., and Dendooven L., 2008. Production of carbon dioxide and nitrous oxide in alkaline saline soil of Texcoco at different water contents amended with urea: A laboratory study. Soil Biol. Biochem., 40, 1813-1822.

Šimek M., Jíšová L., and Hopkins D.W., 2002. What is the socalled optimum $\mathrm{pH}$ for denitrification in soil? Soil Biol. Biochem., 34, 1227-1234.

Stępniewski W. and Stępniewska Z., 2009. Selected oxygendependent process. Response to soil management and tillage. Soil Till. Res., 102, 193-200.

Tavares P., Pereira A.S., Moura J.J.G., and Moura I., 2006. Metalloenzymes of the denitrification pathway. J. Inorg. Biochem., 100, 2087-2100.

Verma A., Tyagi L., Yadav S., and Singh S.N., 2006. Temporal changes in $\mathrm{N}_{2} \mathrm{O}$ efflux from cropped and fallow agricultural fields. Agric. Ecosys. Environ., 116, 209-215.

Vilain G., Garnier J., Tallec G., and Cellier P., 2010. Effect of slope position and use on nitrous oxide $\left(\mathrm{N}_{2} \mathrm{O}\right)$ emissions (Seine Basin, France). Agric. Forest Meteorol., 150, 1192-1202.

Włodarczyk T., 2000. Some aspects of dehydrogenase activity in soils. Int. Agrophysics, 14, 341-354.

Włodarczyk T., Stępniewski W., and Brzezińska M., 2005. Nitrous oxide production and consumption in Calcaric Regosols as related to soil redox and texture. Int. Agrophysics, 19, 263-271.

Yanai Y., Hatano R., Okazaki M., and Toyota K., 2008. Analysis of the $\mathrm{C}_{2} \mathrm{H}_{2}$ inhibition-based $\mathrm{N}_{2} \mathrm{O}$ production curve to characterize the $\mathrm{N}_{2} \mathrm{O}$-reducing activity of denitrifying communities in soil. Geoderma, 146, 269-276. 